\title{
Siew New Disease Reports \\ First report of Turnip yellow virus (TuYV) in Brassica juncea (Indian mustard) in India
}

P. Sharma, R.K. Verma, R. Mishra, D.K. Choudhary and R.K. Gaur*

Department of Science, Faculty of Arts, Science and Commerce, Mody Institute of Technology and Science, Lakshmangarh, Sikar-332311, Rajasthan, India

*E-mail: gaurrajarshi@ hotmail.com

Received: 11 Feb 2013. Published: 18 Jun 2013.

A survey for Turnip yellow virus (TuYV) was carried out during October-December 2012 covering the major field crops in Rajasthan, India. Fifty leaf samples with yellowing and red stripes were collected from Brassica juncea (Indian mustard) fields. The observed symptoms and the presence of a large number of aphids (Myzus persicea) indicated the presence of a virus, possibly TuYV. To confirm the presence of TuYV, total RNA was extracted from infected leaves using the TRIZOL plant mini kit (Invitrogen), according to the manufacturer's protocol. RT-PCR was performed in a single PCR tube with the reaction mixture $(20 \mu \mathrm{l})$ containing $10 \mathrm{ng}$ RNA, $1 \mu \mathrm{l}$ of 20 pmol oligo d(T), $1 \mu \mathrm{l}$ of 20 pmol of Luteovirus group primers Lu1 and Lu4 (Robertson et al., 1991), $2 \mu 1$ of 10x reaction buffer, $0.5 \mu \mathrm{l}$ of $10 \mathrm{mM}$ dNTPs, $0.5 \mu 1$ of $50 \mathrm{mM} \mathrm{MgCl} 2,0.5$ $\mu \mathrm{l}$ of AMV reverse transcriptase and $0.5 \mu \mathrm{l}$ of Taq polymerase $(3 \mathrm{U} / \mu \mathrm{l})$. The RT-PCR was performed in a thermal cycler with the following programme: reverse transcription at $42^{\circ} \mathrm{C}$ for 1 hour, initial denaturation a $94^{\circ} \mathrm{C}$ for $2 \mathrm{~min}$, followed by 35 cycles of $94^{\circ} \mathrm{C}$ for $30 \mathrm{sec}$, annealing at $50^{\circ} \mathrm{C}$ for $1 \mathrm{~min}$, extension at $72^{\circ} \mathrm{C}$ for $1 \mathrm{~min}$ and a final extension of $72^{\circ} \mathrm{C}$ for $10 \mathrm{~min}$. An amplicon of expected size ( 600 nt) (Fig. 1) was sequenced and submitted to GenBank (Accession No. KC570457, isolate RP1) BLAST analysis of the nucleotide sequence showed 91-97\% identity with the corresponding region of TuYV (X13063), Beet western yellows virus (BWYV; L40015, Y11531) and TuYV isolate WA-1 (JQ862472.1).
The nucleotide sequence obtained was used to construct a phylogenetic tree using the neighbour-joining method in MEGA 4.0 tool (Tamura et al., 2007) (Fig. 2). This revealed that the Turnip yellow virus isolate RP1, is closely related to TuYV (BWYV-FL1; X13063). To the best of our knowledge, this is the first report of a natural infection in Brassica juncea by TuYV in India and of a possible association with yellow mosaic and reddening of leaves in the same species.

\section{Acknowledgements}

The authors are thankful to the University Grant Commission, India and the Department of Biotechnology, Government of India (BT/PR14902/BRB/10/889/2010) for providing financial assistance.

\section{References}

Robertson NL, French R, Gray SM, 1991. Use of group-specific primers and the polymerase chain reaction for the detection and identification of luteoviruses. Journal of General Virology 72, 1473-1477. [http://dx.doi.org/10.1099/0022-1317-72-6-1473]

Tamura K, Dudley J, Nei M, Kumar S, 2007. MEGA4: Molecular Evolutionary Genetics Analysis (MEGA) software version 4.0. Molecular Biology and Evolution 24, 1596-1599.

[http://dx.doi.org/10.1093/molbev/msm092]
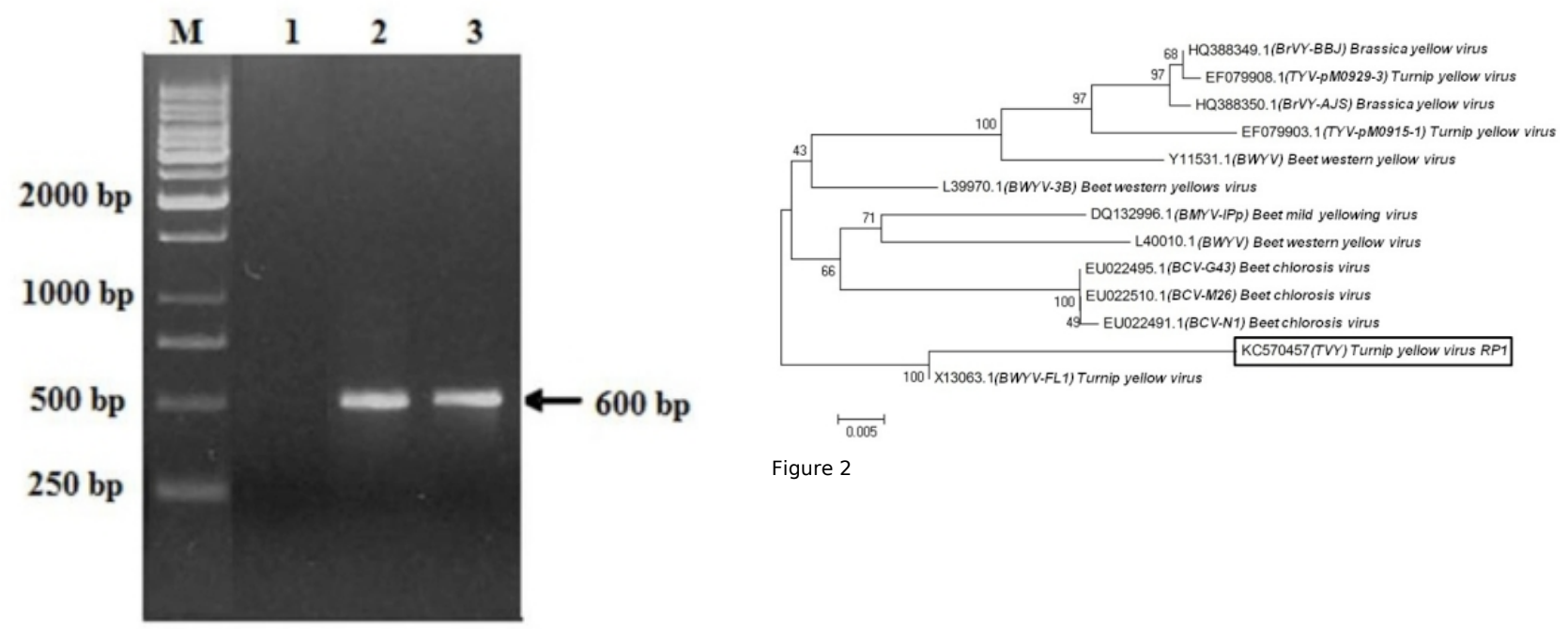

Figure 1

To cite this report: Sharma P, Verma RK, Mishra R, Choudhary DK, Gaur RK, 2013. First report of Turnip yellow virus (TuYV) in Brassica juncea (Indian mustard) in India. New Disease Reports 27, 21. [http://dx.doi.org/10.5197/j.2044-0588.2013.027.021] 